\title{
Guest Molecule-Responsive Functional Calcium Phosphonate Frameworks for Tuned Proton Conductivity
}

Montse Bazaga-García, ${ }^{\dagger}$ Rosario M. P. Colodrero, ${ }^{\dagger}$ Maria Papadaki, ${ }^{\ddagger}$ Piotr Garczarek, ${ }^{\S}$ Jerzy Zoń, $"$

Pascual Olivera-Pastor, ${ }^{\dagger}$ Enrique R. Losilla, ${ }^{\dagger}$ Laura León-Reina, ${ }^{\perp}$ Miguel A. G. Aranda, ${ }^{\dagger, \#}$

Duane Choquesillo-Lazarte, ${ }^{2}$ Konstantinos D. Demadis, ${ }^{* \star \star}$ and Aurelio Cabeza* ${ }^{\dagger}$

†Departamento de Química Inorgánica, Universidad de Málaga, Campus Teatinos s/n, Málaga 29071, Spain

${ }^{\ddagger}$ Crystal Engineering, Growth and Design Laboratory, Department of Chemistry, University of Crete, Voutes Campus, Crete, GR-71003, Greece

${ }^{\S}$ Department of Medicinal Chemistry and Microbiology, Faculty of Chemistry and "Department of Thermodynamics, Institute of Heat Engineering and Mechanics, Faculty of Mechanical and Power Engineering, Wroclaw University of Technology,

27 Wybrzeże Wyspiańskiego, 50-370 Wrocław, Poland

${ }^{\perp}$ Servicios Centrales de Apoyo a la Investigación, SCAI, Universidad de Málaga, Campus Teatinos s/n, 29071-Málaga, Spain

\#CELLS-ALBA Synchrotron, Carretera BP 1413, Km. 3.3, E-08290 Cerdanyola, Barcelona, Spain

${ }^{\nabla}$ Laboratorio de Estudios Cristalográficos, IACT-CSIC, Granada, Spain
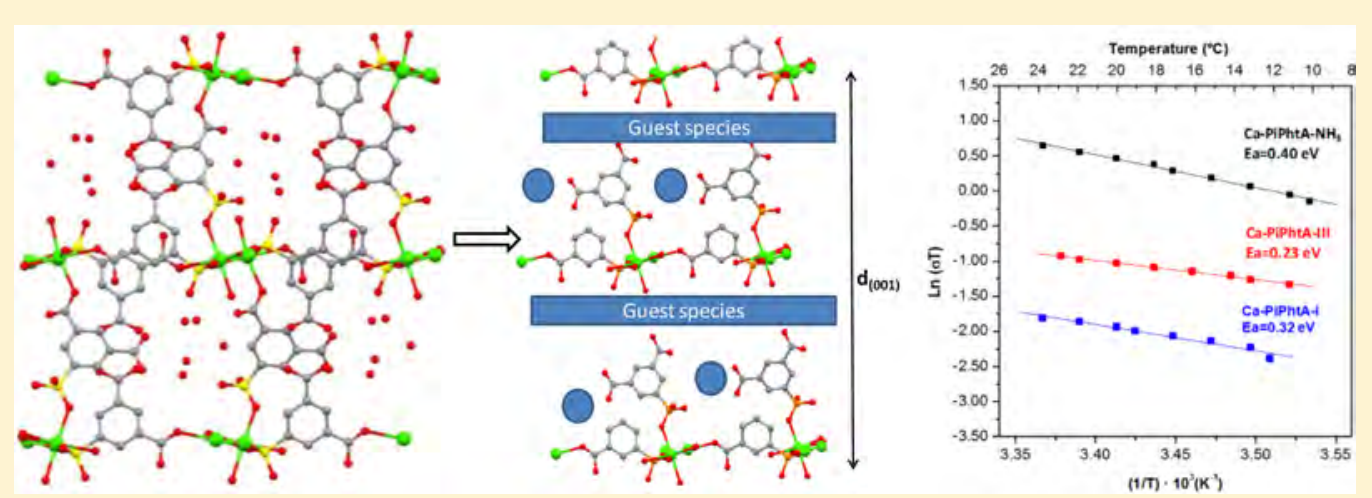

ABSTRACT: We report the synthesis, structural characterization, and functionality (framework interconversions together with proton conductivity) of an open-framework hybrid that combines $\mathrm{Ca}^{2+}$ ions and the rigid polyfunctional ligand 5-(dihydroxyphosphoryl)isophthalic acid (PiPhtA). $\mathrm{Ca}_{2}\left[\left(\mathrm{HO}_{3} \mathrm{PC}_{6} \mathrm{H}_{3} \mathrm{COOH}\right)_{2}\right]_{2}\left[\left(\mathrm{HO}_{3} \mathrm{PC}_{6} \mathrm{H}_{3}(\mathrm{COO})_{2} \mathrm{H}\right)\left(\mathrm{H}_{2} \mathrm{O}\right)_{2}\right] \cdot 5 \mathrm{H}_{2} \mathrm{O}(\mathbf{C a}-\mathbf{P i P h}$ tA-I $)$ is obtained by slow crystallization at ambient conditions from acidic $(\mathrm{pH} \approx 3)$ aqueous solutions. It possesses a high water content (both $\mathrm{Ca}$ coordinated and in the lattice), and importantly, it exhibits water-filled $1 \mathrm{D}$ channels. At $75{ }^{\circ} \mathrm{C}$, Ca-PiPhtA-I is partially dehydrated and exhibits a crystalline diffraction pattern that can be indexed in a monoclinic cell with parameters close to the pristine phase. Rietveld refinement was carried out for the sample heated at $75{ }^{\circ} \mathrm{C}$, Ca-PiPhtA-II, using synchrotron powder X-ray diffraction data, which revealed the molecular formula $\mathrm{Ca}_{2}\left[\left(\mathrm{HO}_{3} \mathrm{PC}_{6} \mathrm{H}_{3} \mathrm{COOH}\right)_{2}\right]_{2}\left[\left(\mathrm{HO}_{3} \mathrm{PC}_{6} \mathrm{H}_{3}(\mathrm{COO})_{2} \mathrm{H}\right)\left(\mathrm{H}_{2} \mathrm{O}\right)_{2}\right]$. All connectivity modes of the "parent" Ca-PiPhtA-I framework are retained in Ca-PiPhtA-II. Upon Ca-PiPhtA-I exposure to ammonia vapors (28\% aqueous $\mathrm{NH}_{3}$ ) a new derivative is obtained (Ca-PiPhtA- $\mathbf{N H}_{3}$ ) containing $7 \mathrm{NH}_{3}$ and $16 \mathrm{H}_{2} \mathrm{O}$ molecules according to elemental and thermal analyses. Ca-PiPhtA-NH $\mathrm{NH}_{3}$ exhibits a complex X-ray diffraction pattern with peaks at 15.3 and $13.0 \AA$ that suggest partial breaking and transformation of the parent pillared structure. Although detailed structural identification of Ca-PiPhtA- $\mathrm{NH}_{3}$ was not possible, due in part to nonequilibrium adsorption conditions and the lack of crystallinity, FT-IR spectra and DTA-TG analysis indicate profound structural changes compared to the pristine Ca-PiPhtA-I. At $98 \% \mathrm{RH}$ and $T=24^{\circ} \mathrm{C}$, proton conductivity, $\sigma$, for $\mathrm{Ca}-\mathrm{PiPhtA}-\mathrm{I}$ is $5.7 \times$ $10^{-4} \mathrm{~S} \cdot \mathrm{cm}^{-1}$. It increases to $1.3 \times 10^{-3} \mathrm{~S} \cdot \mathrm{cm}^{-1}$ upon activation by preheating the sample at $40{ }^{\circ} \mathrm{C}$ for $2 \mathrm{~h}$ followed by water equilibration at room temperature under controlled conditions. Ca-PiPhtA- $\mathrm{NH}_{3}$ exhibits the highest proton conductivity, $6.6 \times 10^{-3} \mathrm{~S} \cdot \mathrm{cm}^{-1}$, measured at $98 \% \mathrm{RH}$ and $\mathrm{T}=24^{\circ} \mathrm{C}$. Activation energies $\left(E_{\mathrm{a}}\right)$ for proton transfer in the above-mentioned frameworks range between 0.23 and $0.4 \mathrm{eV}$, typical of a Grothuss mechanism of proton conduction. These results underline the importance of internal $\mathrm{H}$-bonding networks that, in turn, determine conductivity properties of hybrid materials. It is highlighted that new proton transfer pathways may be created by means of cavity "derivatization" with selected guest molecules resulting in improved proton conductivity.

Received: January 13, 2014

Published: March 18, 2014 


\section{INTRODUCTION}

Metal-organic framework (MOF) materials are now at the epicenter of research efforts of many groups around the globe. An obvious exegesis for the "explosion" in the field is two-fold: (a) new structural motifs are constantly being sought, ${ }^{1 \mathrm{a}}$ and (b) functionality in these materials becomes increasingly important. $^{1 \mathrm{~b}-\mathrm{d}}$ More specifically, potential applications are investigated in fields such as gas adsorption, storage and separation, ${ }^{2}$ magnetism, ${ }^{3}$ catalysis, ${ }^{4}$ photoluminescence, sensors, ${ }^{5}$ controlled release of pharmaceuticals, medicinal and dental materials, ${ }^{6}$ chiral separations, ${ }^{7}$ and ion exchange, ${ }^{8}$ just to mention a few.

A plethora of organic linkers/ligands have been widely utilized to construct these hybrid MOF materials, with the majority being carboxylate, imidazolate, or polypyridyl based. On the other hand, multichelating phosphonate ligands are "alternative" organic linkers (to the widespread polycarboxylates, imidazoles, and various derivatives) and provide synthetic access to a number of thermally and chemically stable MOFs. ${ }^{9}$

Recently, phosphonates, ${ }^{10}$ phosphocarboxylates, ${ }^{11}$ and phosphonosulfonates $^{12}$ that possess an aromatic entity (usually one or more phenyl rings) have been exploited in synthetic efforts, yielding multidimensional (mostly 2D and 3D) platforms.

Proton conductivity has long been investigated as a desirable property in a variety of diverse materials, whether organic, ${ }^{13}$ inorganic, ${ }^{14}$ or hybrid. ${ }^{15}$ The field of MOFs and more specifically metal phosphonates has provided an opportune arena for elegant efforts for accessing suitable and highly conducting materials. ${ }^{15 f, 16}$ Furthermore, postsynthetic modification ${ }^{1 \mathrm{~d}}$ of the internal surfaces of MOFs offers opportunities for enhancing desired properties of crystalline solids. ${ }^{16 c}$ The main requirement for a MOF material to be proton conductive is the presence of acidic protons within an appropriately structured metal-organic framework that facilitates charge transport. In the case of metal phosphonate materials the phosphonic acid group (or partially protonated phosphonate) assumes the role of the acidic group. Such well-ordered structural motifs, with highly ordered phosphonate groups located in close proximity to lattice water molecules, often present appropriate platforms that are candidates for high proton conductivity. ${ }^{12}$ For instance, proton conductivity higher than $10^{-2} \mathrm{~S} \mathrm{~cm}^{-1}$ has been reported for PCMOF21/2, ${ }^{15 f}$ a mixed sulfonate-phosphonate MOF, and for derivatized MIL-101 with $\mathrm{H}_{2} \mathrm{SO}_{4}$ and/or $\mathrm{H}_{3} \mathrm{PO}_{4}{ }^{15 \mathrm{~g}}$ Other notable examples are metal derivatives containing the $\mathrm{N}, \mathrm{N}$-amino-bis(methylenephosphonate) moiety, such as ZrChDTMP ${ }^{17} \mathrm{MgH}_{6} \mathrm{ODTMP},{ }^{18}$ and $\mathrm{LaH}_{5} \mathrm{DTMP},{ }^{19}$ phases, which exhibit conductivity values from $1 \times 10^{-4}$ to $8 \times 10^{-3}$ $\mathrm{S} \mathrm{cm}^{-1}$. The high flexibility imparted by the ligand is considered to exert a key role in determining internal proton transfer pathways.

In the present work, we report the synthesis, structural characterization, and proton conductivity of an open-framework hybrid that combines $\mathrm{Ca}^{2+}$ ions and the rigid polyfunctional ligand 5-(dihydroxyphosphoryl)isophthalic acid (PiPhtA). This material was obtained by slow crystallization at ambient conditions from acidic $(\mathrm{pH} \approx 3)$ aqueous solutions. It possesses a high water content (both Ca coordinated and in the lattice), and importantly, it exhibits water-filled 1D channels. Both characteristics are, in principle, considered to be remarkable attributes to evaluate the proton conductivity of this hybrid compound. The effects of the guest species (water and $\mathrm{NH}_{3}$ ) on the conductivity properties will be highlighted.

\section{EXPERIMENTAL SECTION}

Materials and Common Instrumentation. The starting salt $\mathrm{CaCl}_{2} \cdot 2 \mathrm{H}_{2} \mathrm{O}$ was from EM Science Merck and used as received. Deionized (DI) water from an in-house laboratory cation-exchange column was used for all syntheses. Stock solutions of $\mathrm{HCl}$ and $\mathrm{NaOH}$ were used for $\mathrm{pH}$ adjustments. The $\mathrm{pH}$ meter used was a wTw $\mathrm{pH} 315 \mathrm{i}$ setup, equipped with a SeTix 41 electrode. Elemental analyses $(\mathrm{C}, \mathrm{H}, \mathrm{N})$ were measured on a Perkin-Elmer 240 analyzer. Infrared spectra were collected in a FTIR Nicolet 5DXC spectrometer. All spectra were recorded in the $4000-400 \mathrm{~cm}^{-1}$ range at $4 \mathrm{~cm}^{-1}$ resolution, and 50 scans were accumulated. The ${ }^{1} \mathrm{H},{ }^{13} \mathrm{C}\left\{{ }^{1} \mathrm{H}\right\}$, and ${ }^{31} \mathrm{P}\left\{{ }^{1} \mathrm{H}\right\}$ NMR (see below; operating frequency, solvent) spectra in solution were recorded on a Bruker Avance DRX300 instrument. Chemical shifts $(\delta)$ are given in ppm.

Syntheses. The ligand 5-(dihydroxyphosphoryl)isophthalic acid [5- $\left.\left(\mathrm{H}_{2} \mathrm{O}_{3} \mathrm{P}\right) \mathrm{C}_{6} \mathrm{H}_{3}-1,3-(\mathrm{COOH})_{2}\right]($ PiPhtA, 1) was synthesized through a number of intermediates, shown in Figure 1, as follows.

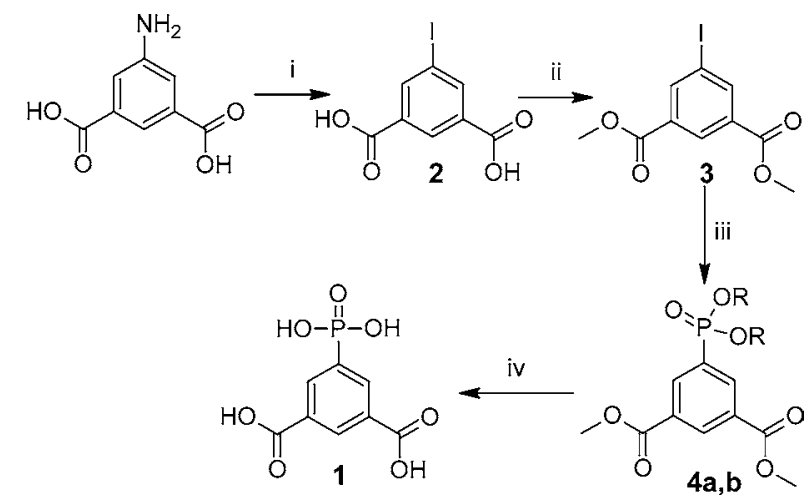

Figure 1. Protocol for the synthesis of 5-(dihydroxyphosphoryl)isophthalic acid (PiPhtA, 1): (i) $\mathrm{NaNO}_{3}, \mathrm{HCl}, \mathrm{KI}$; (ii) $\mathrm{SOCl}_{2}, \mathrm{CH}_{3} \mathrm{OH}$; (iii) $\mathrm{HP}(\mathrm{O})(\mathrm{OR})_{2},\left(\mathrm{i}-\mathrm{C}_{3} \mathrm{H}_{7}\right)_{2} \mathrm{NC}_{2} \mathrm{H}_{5}, \mathrm{Pd}\left(\mathrm{OOCCH}_{3}\right)_{2}, \mathrm{dppf}, \mathrm{CH}_{3} \mathrm{CN}$; (iv) aqueous $\mathrm{HCl}, \mathrm{H}_{2} \mathrm{O}$; $\left(\mathrm{R}=\mathrm{C}_{2} \mathrm{H}_{5}\right)$.

5-lodoisophthalic Acid (2). This compound was prepared from commercially available 5 -aminoisophthalic acid according to a literature procedure. ${ }^{20}$ Specifically, 5-aminoisophthalic acid $(5.00 \mathrm{~g}, 0.0276 \mathrm{~mol})$ was dissolved in a mixture of concentrated hydrochloric acid $\left(49 \mathrm{~cm}^{3}\right)$ and water $\left(49 \mathrm{~cm}^{3}\right)$. This solution was cooled in an ice-water bath, and a solution of sodium nitrite $(2.05 \mathrm{~g}, 0.0295 \mathrm{~mol})$ in water $\left(9.6 \mathrm{~cm}^{3}\right)$ was added with such a rate that the temperature of the mixture did not exceed $4{ }^{\circ} \mathrm{C}$. Next, a solution of potassium iodide $(15.0 \mathrm{~g}, 0.0903 \mathrm{~mol})$ in water $\left(38 \mathrm{~cm}^{3}\right)$ was slowly added. Evolution of nitrogen was observed, and the mixture turned a yellow-reddish color. Afterwards the mixture was refluxed for $1 \mathrm{~h}$. After cooling the precipitate was filtered off and air dried to yield 5-iodoisophthalic acid: $5.76 \mathrm{~g}(72 \%), \mathrm{mp} 284-285{ }^{\circ} \mathrm{C}$ (lit. $288-289^{\circ} \mathrm{C}^{20}$ ).

Dimethyl 5-Iodoisophthalate (3). 5-Iodoisophatlic acid (2, $14.83 \mathrm{~g}$, $0.050 \mathrm{~mol})$ was heated under reflux with thionyl chloride $\left(65 \mathrm{~cm}^{3}\right.$, $0.89 \mathrm{~mol}$ ) for $3.5 \mathrm{~h}$. Next, the excess of thionyl chloride was distilled off. Methanol $\left(50 \mathrm{~cm}^{3}\right)$ was added to the residue carefully due to an exothermic effect and evolution of hydrogen chloride, and the mixture was heated to reflux for a few hours. A precipitate formed during the heating process and was filtered off and recrystallized from methanol to obtain dimethyl 5-iodoisophthalate (3): $13.32 \mathrm{~g}(82 \%), \mathrm{mp} 103-105^{\circ} \mathrm{C}$ (lit. $104^{\circ} \mathrm{C}^{21}$ ).

Dimethyl 5-(Diisopropyloxyphosphoryl)isophthalate (4a). A $50 \mathrm{~cm}^{3}$ round-bottom flask was charged with dimethyl 5-iodoisophthalate $(3,2.00 \mathrm{~g}, 6.25 \mathrm{mmol})$, acetonitrile $(20 \mathrm{~mL})$, diisopropyl phosphite $(1.246 \mathrm{~g}$, $7.5 \mathrm{mmol})$, and diisopropylethylamine $(1.05 \mathrm{~g}, 8.125 \mathrm{mmol})$. The flask was flushed with argon for $15 \mathrm{~min}$, after which palladium acetate $(0.014 \mathrm{~g}, 0.0625 \mathrm{mmol})$ and $1,1^{\prime}$-bis (diphenylphosphine)ferrocene (dppf, $0.038 \mathrm{~g}, 0.0687 \mathrm{mmol}$ ) were added. The reaction mixture was stirred and heated in an oil bath at $90{ }^{\circ} \mathrm{C}$ for $24 \mathrm{~h}$ under constant flow of argon. After cooling to room temperature the mixture was evaporated to dryness in vacuo, and the remaining residue was purified by column 
chromatography on silica gel using ethyl acetate as eluent to yield dimethyl 5-(diisopropyloxyphosphoryl)isophthalate (4a): $1.434 \mathrm{~g}$ $(64 \%), R_{\mathrm{f}}=0.40$ (silica gel on TLC-PET foil, ethyl acetate, UV light $254 \mathrm{~nm}) .{ }^{1} \mathrm{H} \mathrm{NMR}\left(300 \mathrm{MHz}, \mathrm{CDCl}_{3}\right) \delta: 8.82(\mathrm{~m}, 1 \mathrm{H}, \mathrm{CH}$ arom.), 8.63 $\left(\mathrm{dd}, J^{\mathrm{HH}}=1.68 \mathrm{~Hz}, J^{\mathrm{HP}}=16.35 \mathrm{~Hz}, 2 \mathrm{H}, \mathrm{CH}\right.$ arom. $), 4.74(\mathrm{~m}, 2 \mathrm{H}, \mathrm{CH})$, $3.96\left(\mathrm{~s}, 3 \mathrm{H}, \mathrm{CH}_{3}\right), 1.39\left(\mathrm{~d}, J^{\mathrm{HH}}=6.18 \mathrm{~Hz}_{3} \mathrm{CH}_{3}\right), 1.24\left(\mathrm{~d}, J^{\mathrm{HH}}=6.18 \mathrm{~Hz}\right)$. ${ }^{13} \mathrm{C} \mathrm{NMR}\left(75 \mathrm{MHz}, \mathrm{CDCl}_{3}\right) \delta: 165.43,136.64(J=10.94 \mathrm{~Hz}), 133.88$, $131.88(J=192.01 \mathrm{~Hz}), 130.97(J=14.94 \mathrm{~Hz}), 71.51(J=5.59 \mathrm{~Hz})$, 52.60, $24.02(J=3.81 \mathrm{~Hz}), 23.86(J=4.58 \mathrm{~Hz}) \cdot{ }^{31} \mathrm{P}\left\{{ }^{1} \mathrm{H}\right\} \operatorname{NMR}(121$ $\left.\mathrm{MHz}, \mathrm{CDCl}_{3}\right) \delta: 14.16(\mathrm{~s})$.

Dimethyl 5-(Diethoxyphosphoryl)isophthalate (4b). Compound $4 \mathbf{b}$ was synthesized using the same procedure as $4 \mathrm{a}$, starting from $1.173 \mathrm{~g}$ of dimethyl 5-iodoisophthalate, although diethyl phosphite was used. Yield of the ester $4 \mathbf{b}$ : $42 \%, R_{\mathrm{f}}=0.30$ (silica gel on TLC-PET foil, ethyl acetate, UV light $254 \mathrm{~nm}) .{ }^{1} \mathrm{H}$ NMR $\left(300 \mathrm{MHz}, \mathrm{CDCl}_{3}\right) \delta: 8.83(\mathrm{~m}, 1 \mathrm{H}$, $\mathrm{CH}$ arom. $), 8.63\left(\mathrm{dd}, J^{\mathrm{HH}}=1.68 \mathrm{~Hz}, J^{\mathrm{HP}}=13.32 \mathrm{~Hz}, 2 \mathrm{H} \mathrm{CH}\right.$ arom. $), 4.16$ $\left(\mathrm{m}, 4 \mathrm{H}, \mathrm{CH}_{2}\right), 3.96\left(\mathrm{~s}, 6 \mathrm{H}, \mathrm{CH}_{3}\right), 1.34\left(\mathrm{t}, J=7.06 \mathrm{~Hz}, 6 \mathrm{H}, \mathrm{CH}_{3}\right)$. ${ }^{31} \mathrm{P}\left\{{ }^{1} \mathrm{H}\right\}$ NMR $\left(121 \mathrm{MHz}, \mathrm{CDCl}_{3}\right) \delta: 16.33(\mathrm{~s})$.

5-(Dihydroxyphosphoryl)isophthalic Acid (PiPhtA, 1). A $25 \mathrm{~cm}^{3}$ round-bottom flask was charged with dimethyl 5-(diisopropyloxyphosphoryl)isophthalate $(4 \mathrm{a}, 1.072 \mathrm{~g}, 3.00 \mathrm{mmol})$, water $\left(4 \mathrm{~cm}^{3}\right)$, and concentrated hydrochloric acid $\left(4 \mathrm{~cm}^{3}\right)$. The mixture was refluxed for $20 \mathrm{~h}$. After cooling down to room temperature it was evaporated to dryness in vacuo to yield the product $\mathbf{1}$ as a white solid: $0.734 \mathrm{~g}(99 \%) .{ }^{1} \mathrm{H}$ NMR $\left(300 \mathrm{MHz}, \mathrm{D}_{2} \mathrm{O}\right) \delta: 8.29(\mathrm{~d}, J=3.82 \mathrm{~Hz}, 1 \mathrm{H}, \mathrm{CH}$ arom. $), 8.21\left(\mathrm{dd}, J^{\mathrm{HP}}=\right.$ $13.36 \mathrm{~Hz}, J^{\mathrm{HH}}=2.62 \mathrm{~Hz}, 2 \mathrm{H}, \mathrm{CH}$ arom. $)$;. ${ }^{31} \mathrm{P}\left\{{ }^{1} \mathrm{H}\right\} \mathrm{NMR}(121 \mathrm{MHz}$, $\left.\mathrm{D}_{2} \mathrm{O}\right) \delta: 12.63(\mathrm{~s})$.

$\left.\mathrm{Ca}_{2}\left[\left(\mathrm{HO}_{3} \mathrm{P}-\mathrm{C}_{6} \mathrm{H}_{3}-\mathrm{COOH}\right)_{2}\right]_{2}\left[\left(\mathrm{HO}_{3} \mathrm{P}-\mathrm{C}_{6} \mathrm{H}_{3}-(\mathrm{COO})_{2} \mathrm{H}\right)-\left(\mathrm{H}_{2} \mathrm{O}\right)_{2}\right]\right)$. $5 \mathrm{H}_{2} \mathrm{O}$ (Ca-PiPhtA-I). A quantity of the ligand 5-(dihydroxyphosphoryl)isophthalic acid $(1,0.061 \mathrm{~g}, 0.250 \mathrm{mmol})$ was dissolved in $10 \mathrm{~cm}^{3}$ of DI water. A small quantity of a $0.1 \mathrm{M} \mathrm{NaOH}$ stock solution was added dropwise until the ligand dissolved completely and a clear, colorless solution was obtained. A quantity of $\mathrm{CaCl}_{2} \cdot 2 \mathrm{H}_{2} \mathrm{O}(0.037 \mathrm{~g}, 0.250 \mathrm{mmol})$ was separately dissolved in $5 \mathrm{~cm}^{3}$ of DI water. The two solutions were subsequently mixed, and the final solution $\mathrm{pH}$ was adjusted to $3.00 \mathrm{using}$ the $0.1 \mathrm{M} \mathrm{NaOH}$ stock solution. The transparent colorless solution was left undisturbed for 1 week, after which the product appeared as a white crystalline material. It was isolated by filtration, washed with DI water, and air dried. Yield: $92 \%$. Anal. Calcd for $\mathrm{Ca}_{2}\left[\left(\mathrm{HO}_{3} \mathrm{P}-\mathrm{C}_{6} \mathrm{H}_{3}-\right.\right.$ $\left.\mathrm{COOH})_{2}\right]_{2}\left[\left(\mathrm{HO}_{3} \mathrm{P}-\mathrm{C}_{6} \mathrm{H}_{3}-(\mathrm{COO})_{2} \mathrm{H}\right)\left(\mathrm{H}_{2} \mathrm{O}\right)_{2}\right] \cdot 5 \mathrm{H}_{2} \mathrm{O}$, fw 940.56, $\mathrm{C}_{24} \mathrm{H}_{31} \mathrm{Ca}_{2} \mathrm{O}_{28} \mathrm{P}_{3}: \mathrm{C}, 30.81$; H, 2.80. Found: C, 29.27; $\mathrm{H}, 3.36$.

$\mathrm{Ca}_{2}\left[\left(\mathrm{HO}_{3} \mathrm{P}-\mathrm{C}_{6} \mathrm{H}_{3}-\mathrm{COOH}\right)_{2}\right]_{2}\left[\left(\mathrm{HO}_{3} \mathrm{P}-\mathrm{C}_{6} \mathrm{H}_{3}-(\mathrm{COO})_{2} \mathrm{H}\right)-\left(\mathrm{H}_{2} \mathrm{O}\right)_{2}\right]$ (Ca-PiPhtA-II). This compound was obtained by thermal treatment of solid Ca-PiPhtA-I at $75^{\circ} \mathrm{C}$ for $2 \mathrm{~h}$.

Absorption of $\mathrm{NH}_{3}$ Vapors (Aqueous Solution). A $150 \mathrm{mg}$ amount of Ca-PiPhtA-I was placed in contact with vapors from a commercial solution of $28 \mathrm{wt} \%$ of $\mathrm{NH}_{3}$ in water for $2 \mathrm{~h}$ in a closed container. Subsequently, the product was air dried for $15 \mathrm{~min}$ and kept at $98 \%$ relative humidity at $10^{\circ} \mathrm{C}$ for $18 \mathrm{~h}$ following the same procedure described below to measure the proton conductivity. The obtained solid, $\mathrm{Ca}_{2}\left[\left(\mathrm{HO}_{3} \mathrm{P}-\mathrm{C}_{6} \mathrm{H}_{3}-\mathrm{COOH}\right)_{2}\right]_{2}\left[\left(\mathrm{HO}_{3} \mathrm{P}-\mathrm{C}_{6} \mathrm{H}_{3}-(\mathrm{COO})_{2} \mathrm{H}\right)\right]-$ $\left(\mathrm{NH}_{3}\right)_{7}\left(\mathrm{H}_{2} \mathrm{O}\right)_{16}$ (Ca-PiPhtA-NH $\left.\mathbf{N H}_{3}\right)$, has the following elemental analysis. Anal. Calcd: C, 23.69; H, 5.38; N, 8.06. Found: C, 23.86; H, 4.75; N, 7.65. TG -analysis: weight loss up to $400{ }^{\circ} \mathrm{C}$, found $32.67 \%$, calcd $33.36 \%$.

Thermal Analysis. Differential thermal analysis (DTA) and thermogravimetric analysis (TGA) data were recorded on an SDTQ600 analyzer from TA Instruments. The temperature varied from room temperature to $900{ }^{\circ} \mathrm{C}$ at a heating rate of $10^{\circ} \mathrm{C} \cdot \mathrm{min}^{-1}$. Measurements were carried out on samples in open platinum crucibles under a flow of air.

X-ray Crystallography. Laboratory X-ray powder diffraction (XRPD) patterns were collected on a PANanalytical X'Pert Pro automated diffractometer. Powder patterns were recorded in BraggBrentano reflection configuration using a $\mathrm{Ge}(111)$ primary monochromator $\left(\mathrm{Cu} \mathrm{K} \alpha_{1}\right)$ and the X'Celerator detector. Thermodiffractometric studies for Ca-PiPhtA-I and Ca-PiPhtA-NH $\mathrm{NH}_{3}$ were carried out on samples loaded in an Anton Paar HTK 1200N chamber under static air. Data were collected between room temperature and $240{ }^{\circ} \mathrm{C}$. All measurements were performed with a heating rate of $10^{\circ} \mathrm{C} \cdot \mathrm{min}^{-1}$ and a delay time of $5 \mathrm{~min}$ to ensure thermal stabilization. Data acquisition was carried out between $4^{\circ}$ and $40^{\circ}(2 \theta)$ due to "less-than-ideal" crystallinity of the samples. A step size of $0.017^{\circ}$ and an equivalent counting time of $150 \mathrm{~s}^{-1}$ step $^{-1}$ were used.

Crystal Structure Determination. Suitable-size crystals of Ca-PiPhtA-I were kept under inert conditions and immersed in perfluoropolyether as protecting oil for manipulation. A suitable crystal was mounted on MiTeGen Micromounts, and this sample was used for data collection. Data were collected with a Bruker SMART APEX diffractometer. Data were processed with $\mathrm{APEX}^{22}$ suite and corrected for absorption using SADABS. ${ }^{23}$ The structure was solved by direct methods, ${ }^{24}$ which revealed the position of all non-hydrogen atoms. These atoms were refined on $F^{2}$ by a full-matrix least-squares procedure using anisotropic displacement parameters. ${ }^{24}$ All hydrogen atoms were located in difference Fourier maps, except those corresponding to $\mathrm{C}-\mathrm{H}$ groups, which were placed geometrically and included as fixed contributions riding on attached atoms with isotropic thermal displacement parameters $1.2(\mathrm{C}-\mathrm{H})$ or $1.5(\mathrm{O}-\mathrm{H})$ times those of the respective bonded atom.

Synchrotron X-ray powder diffraction data (SXRDP) for Ca-PiPhtAII were collected in Debye-Scherrer (transmission) mode using the $\mathrm{X}$-ray powder diffraction station of ALBA, the Spanish Synchrotron Radiation Facility (Barcelona, Spain). ${ }^{25}$ The wavelength, 0.62020(1) $\AA$, was selected with a double-crystal Si (111) monochromator and determined from a Si640d NIST standard $(a=5.43123 \AA)$ measurement. The capillary was rotated during data collection to improve diffracting particle statistics. The detector system used was the MYTHEN, which allows fast collection of good-resolution patterns. The data acquisition time was $\sim 20$ min per pattern to attain very good signal-to-noise ratio over the angular range $1-41^{\circ}(2 \theta)$.

The X-ray powder pattern was autoindexed using the DICVOL06 program. ${ }^{26}$ The crystal structure of Ca-PiPhtA-II compound was determined by the Rietveld method ${ }^{27}$ using the structure of Ca-PiPhtAI available from single-crystal data as starting model. Rietveld refinement was carried out using the GSAS package ${ }^{28}$ with soft constraints to maintain chemically reasonable geometries for the phosphonate, aromatic ring, and carboxylic groups. The soft constraints were as follows: $/ \mathrm{PO}_{3} \mathrm{C}$ tetrahedron $/ \mathrm{P}-\mathrm{O}, 1.53(1) \AA$; $\mathrm{P}-\mathrm{C}, 1.80(1) \AA$ 的 $\mathrm{O} \cdots \mathrm{O}$,

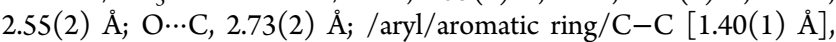
$\mathrm{C}_{\text {ring }} \cdots \mathrm{C}_{\text {ring }}[2.40(1) \AA], \mathrm{C}_{\text {ring }} \cdots \mathrm{C}_{\text {ring }}[2.78(1) \AA], / \mathrm{COO}$ group/, $\mathrm{C}_{\text {aryl }}{ }^{-}$ $\mathrm{C}_{\text {carb }}[1.50(1) \AA], \mathrm{C}-\mathrm{O}_{\text {carb }}[1.23(1) \AA], \mathrm{O}_{\text {carb }} \cdots \mathrm{O}_{\text {carb }}, 2.21(2) \AA ; \mathrm{C}_{\text {aryl }} \cdots$ $\mathrm{O}_{\text {carb }}, 2.36(2) \AA$. . Two isotropic atomic displacement parameters were refined, one for calcium and phosphorus atom and a second one for carbon and oxygen atoms. Hydrogen atoms were not included in the refinements. Crystallographic data and CCDC reference codes are given in Table 1.

Proton Conductivity Studies. Impedance data were collected on cylindrical pellets ( $\sim 10 \mathrm{~mm}$ diameter; $\sim 0.9-1.1 \mathrm{~mm}$ thickness) obtained by pressing $\sim 0.15 \mathrm{~g}$ of sample at $500 \mathrm{MPa}$ for 2 min between porous $\mathrm{C}$ electrodes (Sigracet, GDL $10 \mathrm{BB}$, no Pt). Impedance data were collected using a HP4284A impedance analyzer over the frequency range from $20 \mathrm{~Hz}$ to $1 \mathrm{MHz}$ with an applied voltage of $1 \mathrm{~V}$. All measurements were electronically controlled by the winDETA package of programs. $^{29}$

Electrical measurements were taken in a double-walled, temperaturecontrolled glass chamber with a gas inlet and outlet. The temperature of the chamber was controlled by a Julabo F32-MA refrigerated/heating circulator from 10 to $24{ }^{\circ} \mathrm{C}$ every $2{ }^{\circ} \mathrm{C}$ with a heating rate of $0.4^{\circ} \mathrm{C} \cdot \mathrm{min}^{-1}$ using EasyTEMP software. Samples were equilibrated for $15 \mathrm{~min}$ after each step in temperature, measured in closest vicinity to the sample. The relative humidity $(\mathrm{RH})$ was obtained by a continuous flow of water-saturated nitrogen at different temperatures through the cell. Pellets were equilibrated at $98 \% \mathrm{RH}$ for $18 \mathrm{~h}$ to ensure a fixed water content of the sample and stable conductivity values. $\mathrm{RH}$ is approximately constant in the measured temperature range from 10 to $24^{\circ} \mathrm{C}$.

\section{RESULTS AND DISCUSSION}

Synthesis. The product Ca-PiPhtA-I is formed at a relatively low reaction $\mathrm{pH}(\sim 3.0)$. At this $\mathrm{pH}$ the carboxylic acid groups are 
Table 1. Crystallographic Data for Ca-PiPhtA-I and Ca-PiPhtA-II

\begin{tabular}{|c|c|c|}
\hline & Ca-PiPhtA-I & Ca-PiPhtA-II \\
\hline chemical formula & $\mathrm{Ca}_{2} \mathrm{C}_{24} \mathrm{H}_{31} \mathrm{O}_{28} \mathrm{P}_{3}$ & $\mathrm{Ca}_{2} \mathrm{C}_{24} \mathrm{H}_{21} \mathrm{O}_{23} \mathrm{P}_{3}$ \\
\hline formula mass & 940.56 & 850.49 \\
\hline cryst syst & orthorhombic & monoclinic \\
\hline $\begin{array}{l}\text { cryst size }(\mathrm{mm}) \text { color/ } \\
\text { shape }\end{array}$ & $\begin{array}{l}0.10 \times 0.09 \times 0.08 \text { colorless } / \\
\quad \text { block }\end{array}$ & \\
\hline$\lambda / \AA$ & 0.71073 & $0.62020(1)$ \\
\hline$a / \AA ̊$ & $23.112(4)$ & $23.0652(7)$ \\
\hline$b / \AA ̊$ & $6.9534(13)$ & $6.9731(1)$ \\
\hline$c / \AA$ & $22.638(4)$ & $22.4165(7)$ \\
\hline$\alpha / \operatorname{deg}$ & 90.0 & 90 \\
\hline$\beta / \operatorname{deg}$ & 90.0 & $91.540(4)$ \\
\hline$\gamma / \operatorname{deg}$ & 90.0 & 90 \\
\hline unit cell volume $/ \AA^{3}$ & $3638.1(12)$ & $3604.1(2)$ \\
\hline temp $/{ }^{\circ} \mathrm{C}$ & -173 & 25 \\
\hline space group & $\mathrm{Pca2}_{1}$ & $\mathrm{~Pa}$ \\
\hline$Z$ & 4 & 4 \\
\hline$R_{\text {int }}$ & 0.0832 & \\
\hline no. of independent reflns & 4603 & 3455 \\
\hline $\begin{array}{l}\text { data (reflns)/restraints/ } \\
\text { params }\end{array}$ & $6716 / 1 / 522$ & $5500 / 299 / 357$ \\
\hline$R$ factor $[I>2 \sigma(I)]$ & $\mathrm{R} 1^{a}=0.0715 ; \mathrm{wR} 2^{a}=0.1610$ & \\
\hline$R$ factor (all data) & $\mathrm{R} 1^{a}=0.1075 ; \mathrm{wR} 2^{a}=0.1834$ & \\
\hline$R_{\mathrm{WP}}$ & & 0.0654 \\
\hline$R_{\mathrm{P}}$ & & 0.0464 \\
\hline $\mathrm{GoF} / R_{\mathrm{F}}$ & 1.032 & 0.075 \\
\hline CCDC number & 968321 & 968322 \\
\hline \multicolumn{3}{|c|}{${ }^{a} \mathrm{R} 1(\mathrm{~F})=\Sigma\left\|F_{\mathrm{o}}|-| F_{\mathrm{c}}\right\| / \Sigma\left|F_{\mathrm{o}}\right| ; \mathrm{wR} 2\left(F^{2}\right)=\left[\Sigma w\left(F_{\mathrm{o}}{ }^{2}-F_{\mathrm{c}}^{2}\right)^{2} / \Sigma F^{4}\right]^{1 / 2}$} \\
\hline
\end{tabular}

expected to be deprotonated, whereas the phosphonic acid group is monodeprotonated. This would render the ligand trianionic, and a possible 1:1 adduct with $\mathrm{Ca}^{2+}$ would be anionic. However, based on elemental analyses and the structure solved, a solid with a Ca:ligand ratio of 2:3 is instead obtained, indicating that the protonation state of the ligand is complex. As suggested by the empirical formula, the ligand is found in different protonation states, which are adjusted depending on the various modes of coordinating to $\mathrm{Ca}^{2+}$ (Figure 2).

Structural Study. Ca-PiPhtA-I shows a complex pillared layered structure with a unit cell containing two calcium atoms, three PiPhtA ligands, and seven water molecules (two are Ca coordinated and the remaining five are situated within the lattice). The coordination geometry of both calcium centers is pentagonal bipyramidal (see Figure 3).

In this geometry, four of the equatorial positions are occupied by oxygen atoms of three different phosphonate groups, one of them chelating the metal ion in a bidentate fashion. The fifth equatorial coordination position is occupied by an oxygen atom of a carboxylate group. All of these equatorial oxygen atoms belong to two ligands, P2 and P3, which configure edge-sharing calcium polyhedral chains and connect them into the layers, while leaving alternately arranged free carboxylic groups inside the interlayer space (Figure 4). The axial positions of the calcium polyhedron are occupied by a water molecule and a phosphonate or carboxylate oxygen of the third organic ligand, P1, which is pillaring adjacent layers.

Within the layers, each phosphonate moiety uses only two oxygen atoms to coordinate calcium in such a way that one oxygen atom is bridging two metal centers, thus leaving a free $\mathrm{POH}$ pointing to the interlayer space. One of the carboxylate moieties of both dicarboxyphosphonate ligands, P2 and P3, is<smiles>O=C=C=COC(=O)c1cc(C(=O)O)cc(C(=O)OC(=O)c2cc(C(=O)O)cc(P(=O)(O)O)c2)c1</smiles>

A

B

C

Figure 2. Three deprotonation states of the ligand PiPhtA in the structure of Ca-PiPhtA-I.

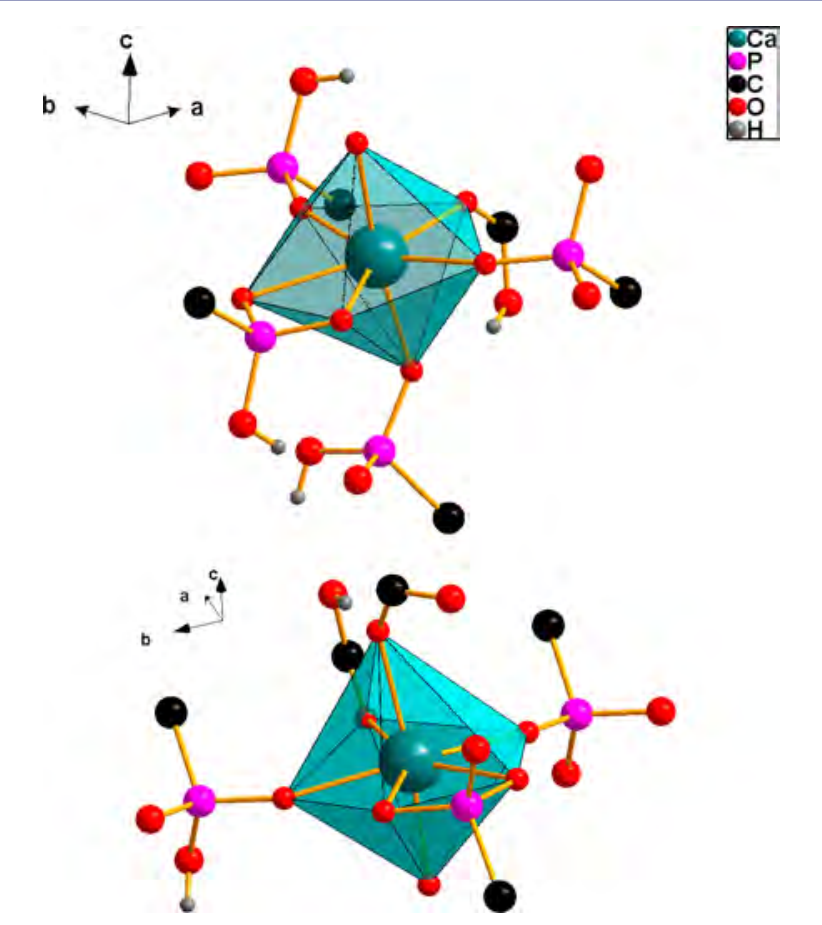

Figure 3. Coordination environment of the two Ca centers in the structure of Ca-PiPhtA-I.

coordinated to calcium atoms through one of the oxygens, while the other one is protonated. Besides, the second carboxylic group of each these ligands is pointing toward the interlayer space and faced up to each other interacting strongly by a H-bond. This disposition creates $\mathrm{H}$-bond rings contributing to the stabilization of the pillared layered structure. The third dicarboxyphosphonate ligand, P1, is linking adjacent layers only by one phosphonate oxygen, by one side, and one carboxylate oxygen atom, from the other side. This connectivity mode leaves a $\mathrm{POH}$ and a free carboxylic group inside the interlayer space (see Figure 4).

The overall structure architecture reveals interlayer hydrophilic 1-D channels running parallel to the $b$ axis, filled with five lattice waters per unit cell forming zigzag chains inside the cavities (Figure 5).

The parallel zigzag chains acquire a left-handed helix and a right-handed helix along the $c$ axis. The water-to-water interactions between these lattice waters create an extended network of $\mathrm{H}$ bonds along the 1-D channels and therefore a potential proton transfer pathway, which may play an important role in the proton conductivity exhibited by the Ca-PiPhtA materials (see Table S1, Supporting Information).

The title compound shares some similarities with compounds $\mathrm{Ca}_{2}\left(\mathrm{H}_{2} \mathrm{O}\right)\left[\mathrm{H}(\mathrm{OOC})_{2} \mathrm{C}_{6} \mathrm{H}_{3} \mathrm{PO}_{3} \mathrm{H}\right]_{2}$ and $\left[\mathrm{Sm}_{2}\left(\mathrm{H}_{2} \mathrm{O}\right)_{4}(\mathrm{H}-\right.$ $\left.\left.(\mathrm{OOC})_{2} \mathrm{C}_{6} \mathrm{H}_{3} \mathrm{PO}_{3}\right)_{2}\right] \cdot 2 \mathrm{H}_{2} \mathrm{O}$ obtained by hydrothermal treatment. ${ }^{30}$ In the former, each ligand is 2 -fold deprotonated resulting 


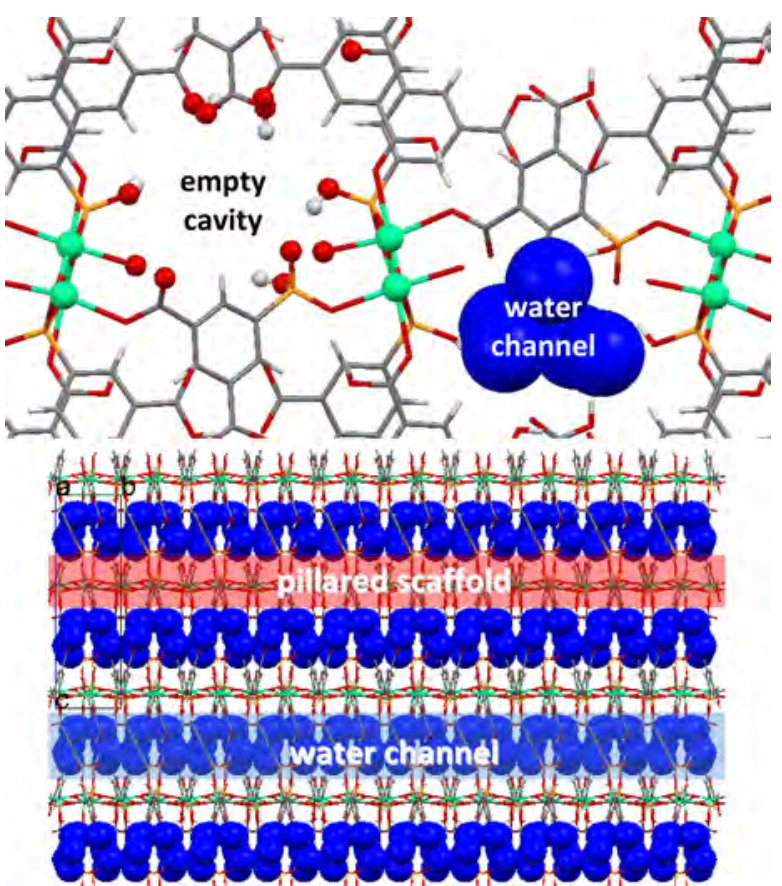

Figure 4. (Top) 3D structure of Ca-PiPhtA-I along the $b$ axis, showing the relative arrangement of the water-filled $1 \mathrm{D}$ channels and the moieties protruding from the channel wall to the interior. (Bottom) Longitudinal view ( $b$-axis horizontal) of the $1 \mathrm{D}$ water columns within the pillared scaffold.

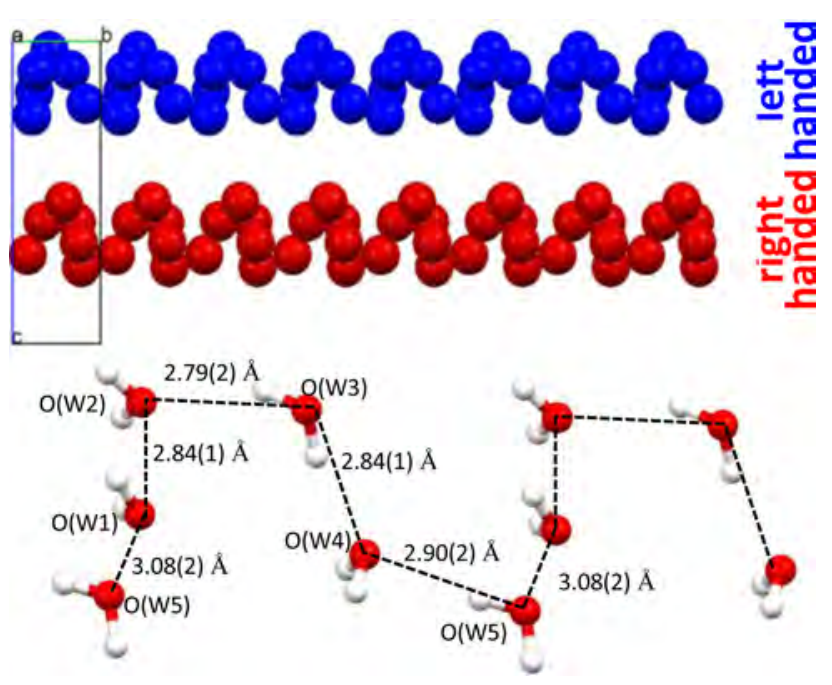

Figure 5. (Top) Two neighboring water channels. Upper channel (in blue) represents a left-handed helix, whereas the lower (in red) represents a right-handed helix. (Bottom) Close contacts between the $\mathrm{O}$ atoms within a water channel.

in three distinctive coordinating groups, one carboxylate, one carboxylic, and one hydrogen phosphonate group. $\mathrm{Ca}^{2+}$ ions are also coordinated by seven oxygen atoms, and $\mathrm{Ca}$ polyhedrons are found sharing edges. However, only discrete $\mathrm{Ca}_{2} \mathrm{O}_{12}$ dimers are present in the structure of the reported Ca derivative instead of lineal chains. In addition, the connectivity of the three groups is also modified, the title compound showing a higher connectivity of the hydrogen phosphonate groups relative to the carboxylate/ carboxylic groups. Regarding the samarium derivative, the main structural feature common with the title compound is the presence of edge-sharing $\mathrm{Sm}$ polyhedron chains. However, differently, $\mathrm{Sm}^{3+}$ is nine coordinated and, additionally, side arms of edge-sharing polyhedra of $\mathrm{Sm}^{3+}$ are attached to the main chain. Thus, the chains are interconnected by phosphonate and carboxylate groups coordinated to $\mathrm{Sm}^{3+}$ ions, giving hybrid layers interconnected by hydrogen bonding between two carboxylic acid groups.

FT-IR Spectroscopy. Comparison of the FT-IR spectrum of the "free" ligand PiPhtA with that of Ca-PiPhtA-I is revealing. The ligand shows antisymmetric $\nu(\mathrm{C}=\mathrm{O})$ stretches at 1705 , 1665 , and $1599 \mathrm{~cm}^{-1}$ and symmetric $\nu(\mathrm{C}-\mathrm{O})$ stretches at 1454 , 1437, and $1395 \mathrm{~cm}^{-1}$. These are shifted in the spectrum of CaPiPhtA-I, with the antisymmetric $\nu(\mathrm{C}=\mathrm{O})$ stretches appearing at 1692,1605 , and $1572 \mathrm{~cm}^{-1}$ and the symmetric $\nu(\mathrm{C}-\mathrm{O})$ stretches located at 1434,1406 , and $1381 \mathrm{~cm}^{-1}$. Such shifts upon ligand coordination in bands associated with the carboxylate group are well established in the literature. ${ }^{31}$ There are also notable shifts in the vibrations related to the phosphonate group. There is a set of three strong intensity bands in the ligand spectrum at 1109,1135 , and $1242 \mathrm{~cm}^{-1}$, which are appropriately shifted to 1132,1255 , and $1278 \mathrm{~cm}^{-1}$ in the compound spectrum. These are assigned to the $-\mathrm{PO}_{3}$ antisymmetric stretch. Lastly, a band at $932 \mathrm{~cm}^{-1}$ in the ligand spectrum assigned to the $\mathrm{P}-\mathrm{O}$ stretch shows up at $913 \mathrm{~cm}^{-1}$ in the compound spectrum (Figure S1, Supporting Information). All phosphonate-related bands appear in the same region as that reported for several other metal phosphonate materials.

Thermal Behavior. The thermal stability of Ca-PiPhtA-I compound was studied by TG-DTA analysis and X-ray thermodiffraction. The TG and heat flow curves, Figure 6,

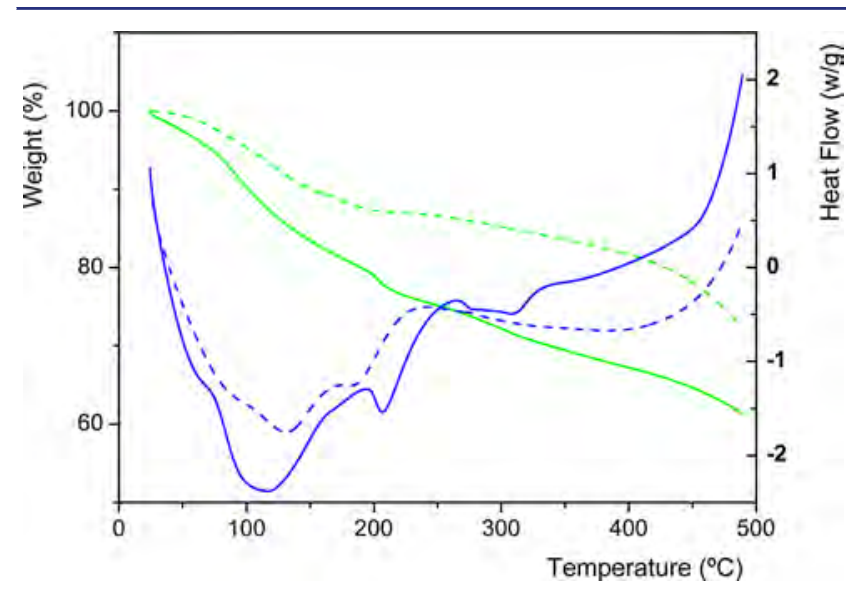

Figure 6. TGA (green) and DTA (blue) curves for Ca-PiPhtA-I (dashed line) and after adsorption of $\mathrm{NH}_{3}$, Ca-PiPhtA- $\mathrm{NH}_{3}$ (solid lines).

show that dehydration of the solid takes place in three overlapping steps between 50 and $220{ }^{\circ} \mathrm{C}$. The two first steps are centered at 75 and $130{ }^{\circ} \mathrm{C}$ and correspond to removal of five lattice waters (observed weight loss 9.63\%, calculated 9.62\%). The third step, centered at $180{ }^{\circ} \mathrm{C}$, is due to elimination of the Ca-bound water. The dehydration process ends at $220^{\circ} \mathrm{C}$ with an associated weight loss of $13.24 \%$, which is consistent with the loss of seven water molecules (calculated 13.5\%) and the results from the crystallographic study. Above this temperature, a small but progressive mass loss is observed that suggests partial decomposition of the solid before combustion of the organic moieties at $380{ }^{\circ} \mathrm{C}$.

Dehydration of Ca-PiPhtA-I was also followed by thermodiffraction (Figure 7). Although no water is lost between room temperature and $50{ }^{\circ} \mathrm{C}$, a slight change in the symmetry of the 


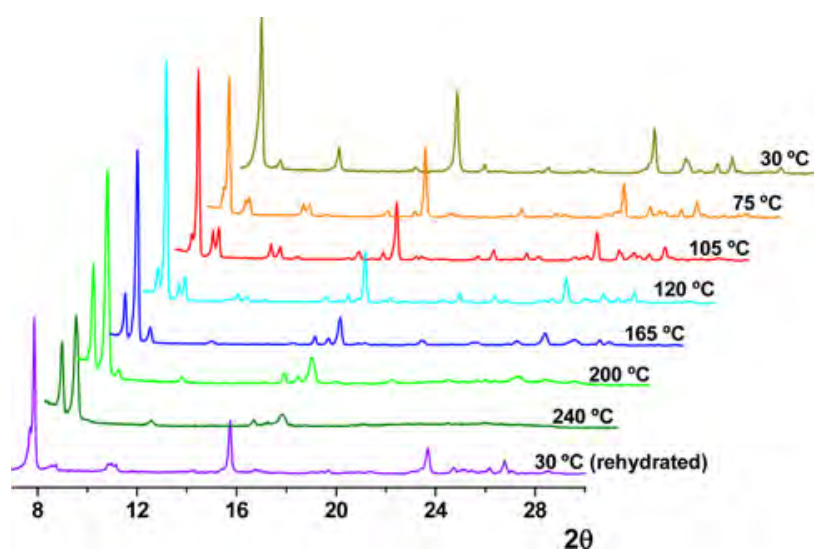

Figure 7. Thermodiffractometric study for Ca-PiPhtA-I at selected temperatures.

compound is already apparent in this temperature range, as indicated by the splitting of some of the diffraction peaks. At $75^{\circ} \mathrm{C}$, the sample is partially dehydrated and exhibits a diffraction pattern that can be indexed in a monoclinic cell with parameters very close to the "as-synthesized sample". This framework remains stable upon heating up to $135^{\circ} \mathrm{C}$, as confirmed by the corresponding LeBail fits. The appearance of additional diffraction peaks in the range $135-220{ }^{\circ} \mathrm{C}$, which cannot be indexed in the monoclinic cell, is indicative of further structural changes taking place concurrently with removal of the coordinated water and a progressive loss of crystallinity. However, the crystallinity is restored when the sample preheated at $220{ }^{\circ} \mathrm{C}$ is exposed to air or put in contact with a controlled humidity atmosphere (saturated $\mathrm{K}_{2} \mathrm{SO}_{4}$ solution) at room temperature for 4 days (Figure 7 ). The resulting diffraction pattern agrees well with a mixture of the orthorhombic and monoclinic phases. Thermogravimetric analysis also reveals that this sample is fully rehydrated ( $13.39 \%$ of weight loss at $250{ }^{\circ} \mathrm{C}$ ).

Rietveld refinement was carried out for the sample heated at $75^{\circ} \mathrm{C}$, Ca-PiPhtA-II, in order to gain better insight on the structural identity of the monoclinic phase. For refinement, the crystal structure of Ca-PiPhtA-I was used as a starting model after reducing symmetry to the monoclinic space subgroup $P a$. A total of 104 atoms in the asymmetric unit were refined using synchrotron powder X-ray diffraction data. The final Rietveld plot is given as Supporting Information (Figure S2). The water content for this sample was determined to be $9.70 \%$ by thermogravimetric analysis, at a time scale similar to that of the thermodiffractometric study. The weight loss agrees well with complete removal of the lattice water.

Removal of lattice waters provokes small structural changes, according to the refined unit cell parameters (see Table 1), which are more significant along the pillaring direction ( $c$ axis). The resulting monoclinic phase, Ca-PiPhtA-II, has $4 \mathrm{Ca}$ atoms, 6 ligands, and 4 water molecules in the asymmetric unit. All connectivity modes of the "parent" Ca-PiPhtA-I framework are retained in Ca-PiPhtA-II. However, the higher complexity of the unit cell results in higher distortion of the calcium polyhedra and hence formation of an alternate interlayer region with slightly different cavity dimensions (see Figure 8), the alteration of the axial angles $\mathrm{O}-\mathrm{Ca}-\mathrm{O}$ along the $c$ axis being the most significant structural change in the monoclinic cell. Hence, new $\mathrm{O}_{5 \mathrm{~b}}-\mathrm{C}_{\mathrm{alb}}-$ $\mathrm{O}_{\mathrm{w} 6 \mathrm{~b}}=153(3)^{\circ}$ and $\mathrm{O}_{1 \mathrm{~b}}-\mathrm{Ca}_{2}-\mathrm{O}_{\mathrm{w} 76}=153(3)^{\circ}$ angles are observed, together with $\mathrm{O}_{\mathrm{ax}}-\mathrm{Ca}-\mathrm{O}_{\mathrm{ax}}$ angles close to $180^{\circ}$ characteristic of the orthorhombic cell. A consequence of these
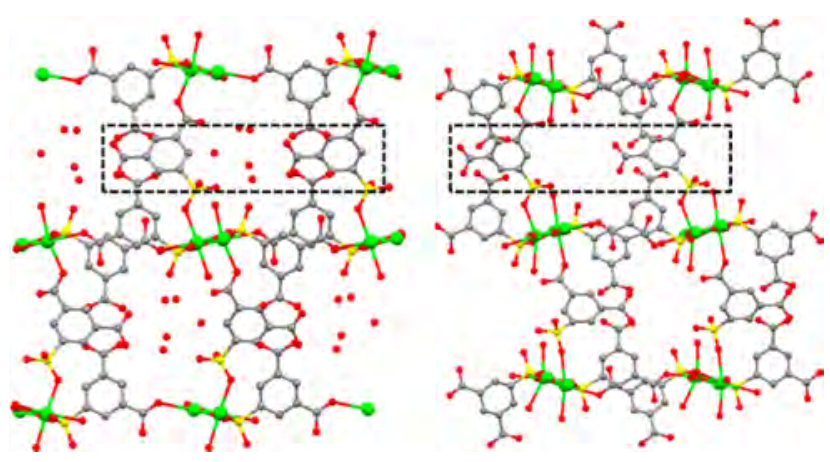

Figure 8. $b$-axis view ( $a$-axis horizontal) of the crystal structures for CaPiPhtA-I (left) and Ca-PiPhtA-II (right) showing the slightly different conformation of the 1D channels along the $c$ axis.

changes in the interlayer region of the monoclinic cell is the appearance of asymmetric $\mathrm{H}$-bond rings between facing-up carboxylic groups, with interaction distances $-\mathrm{COO}-\mathrm{H} \cdots \mathrm{O}-$ $\mathrm{C}-\mathrm{OH}-$ of 2.1 and $2.8 \AA$. The existence of different 1-D channels may affect the $\mathrm{H}$-bond strength in the monoclinic cell upon rehydration.

Absorption of $\mathrm{NH}_{3}$ Vapors. Ca-PiPhtA-I was exposed to vapors from a concentrated aqueous ammonia solution (28\%). A new derivative was obtained (Ca-PiPhtA- $\mathbf{N H}_{3}$ ) containing 7 $\mathrm{NH}_{3}$ and $16 \mathrm{H}_{2} \mathrm{O}$ molecules according to elemental and thermal analyses. This material exhibits a complex X-ray diffraction pattern with peaks at 15.3 and $13.0 \AA$ A that suggest partial breaking of the pillared structure (Figure S3, Supporting Information). This hypothesis is strongly supported by the inability of the original narrow 1-D channels to accommodate the high number (23) of intercalated guest species. Although a detailed structural analysis of Ca-PiPhtA-NH $\mathbf{N H}_{3}$ has not yet been possible, due in part to the lack of crystallinity, inspection of the IR spectra and DTATG analysis indicate profound structural changes compared to the pristine Ca-PiPhtA-I. Hence, in addition to the characteristic IR bands corresponding to metal carboxyphosphonates observed for Ca-PiPhtA-I and in agreement with the crystallographic data, ${ }^{32}$ the IR spectrum of Ca-PiPhtA- $\mathbf{N H}_{3}$ (Figure S1, Supporting Information) shows a shift to lower wave numbers in the water stretching vibrations region, which is indicative of the existence of strong hydrogen bonds between intercalated water and ammonia guest molecules. In addition, the characteristic bands corresponding to the carboxylic ${ }^{31}\left(\sim 1700 \mathrm{~cm}^{-1}\right)$ and hydrogen phosphonate ${ }^{33}\left(915-930 \mathrm{~cm}^{-1}\right)$ groups are practically absent in the vibrational spectrum of Ca-PiPhtA- $\mathbf{N H}_{3}$ as a consequence of the reaction of these acidic groups with $\mathrm{NH}_{3}$. In addition, the DTA-TG curves of the ammonia derivative Ca-PiPhtA- $\mathrm{NH}_{3}$ (Figure 6) show a higher guest molecule content between room temperature and $400{ }^{\circ} \mathrm{C}$. Importantly, a different weight loss profile is noted, revealing a new endothermic peak at $210{ }^{\circ} \mathrm{C}$, indicative of strongly retained guest species. Thermodiffraction of Ca-PiPhtA- $\mathbf{N H}_{3}$ shows a progressive amorphization of the sample with removal of the guest species, although the peak at $15.3 \AA$ (corresponding to the new intercalated phase) persists up to $125^{\circ} \mathrm{C}$. This is a good indication of the high stability of this phase.

In the absence of precise structural data, we speculate that Ca-PiPhtA- $\mathrm{NH}_{3}$ is a multiphase compound with peaks at 15.3 and $13 \AA$ representing the $d_{(\mathrm{oo} 2)}$ basal spacing of two new layered phases originated by rupture of the interlayer phosphonate/ $\mathrm{Ca}^{2+}$ or carboxylate/Ca ${ }^{2+}$ bonds (see Figure 9). The similar bond lengths for the distances $\mathrm{Ca}-\mathrm{O}_{\text {carboxylate }}[2.378(9) \AA]$ and 

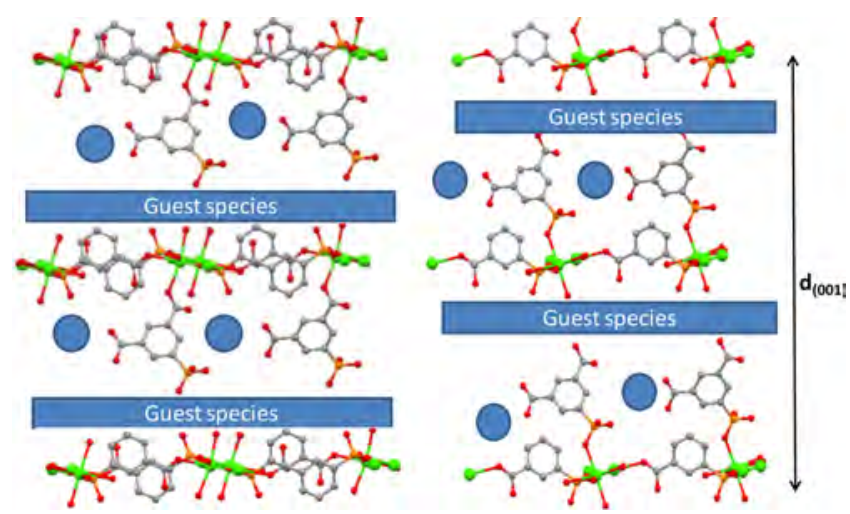

Figure 9. Schematic representation for the rupture of the 3D framework to give new $2 \mathrm{D}$ intercalated derivatives.

$\mathrm{Ca}-\mathrm{O}_{\text {phosphonate }}[2.394(9) \AA]$ may support both breaking mechanisms. Other phases at lower $d$ spacing, if existing, are more difficult to distinguish due to overlapping with other reflections of the crystal. The reactivity of Ca-PiPhtA-I toward a concentrated solution of ammonia is in clear contrast to the almost inexistent adsorption by running a typical $\mathrm{NH}_{3}-\mathrm{TPD}$ experiment on a sample previously dehydrated at $200{ }^{\circ} \mathrm{C}$. This suggests that ammonia and water adsorption occurs through a cooperative mechanism of hydrogen-bond interaction.

Proton Conductivity Study. The Ca-PiPhtA-I framework possesses 1D channels hosting zigzag chains of water molecules that simultaneously interact with the pendant- $\mathrm{POH}$ and $-\mathrm{COOH}$ groups. These structural features prompted us to undertake a study of its proton conductivity. Effective pathways for proton transfer could be created through the H-bond interactions among the acidic groups and both lattice and Ca-bound water molecules. Thermogravimetric analysis revealed that the starting samples exposed to $98 \% \mathrm{RH}$ were fully hydrated, as the measured weight losses were very close to the observed value of $13 \%$ at $250{ }^{\circ} \mathrm{C}$ for the as-synthesized material Ca-PiPhtA-I. All conductivity measurements were carried out after equilibration for $18 \mathrm{~h}$ to ensure that the samples exhibit stable conductivity values and were fully reproducible after several cycles of measurements (Figure S4, Supporting Information).

The impedance plots, Figure 10, show similar features with spikes inclined to the $Z^{\prime}$ axis by $\sim 70^{\circ}$, indicating a partialblocking electrode response that allows limited diffusion and, therefore, confirms the conducting species must be ionic, i.e., $\mathrm{H}^{+}$ions. The total pellet resistances, $R_{\mathrm{T}}$, were obtained from the intercept of the spikes and/or the arcs (low frequency end) on the $Z^{\prime}$ axis. At $98 \% \mathrm{RH}$ and $T=24^{\circ} \mathrm{C}$, the conductivity values, $\sigma$, are $5.7 \times 10^{-4}$ and $3.6 \times 10^{-4} \mathrm{~S} \cdot \mathrm{cm}^{-1}$ for Ca-PiPhtA-I and Ca-PiPhtA-II, respectively. These conductivities rise up to $1.3 \times$ $10^{-3} \mathrm{~S} \cdot \mathrm{cm}^{-1}$ upon preheating the sample at $40^{\circ} \mathrm{C}$ for $2 \mathrm{~h}$ and subsequently water-equilibrated (Ca-PiPhtA-III). The X-ray diffraction pattern for Ca-PiPhtA-III is similar to that of Ca-PiPhtA-I, and its water content remains unchanged as confirmed by thermal analysis. We attribute the increase in conductivity to a thermal activation mechanism implying small but effective structural and/or textural changes (surface effect) leading to an enhancement of the proton conduction properties.

The conductivity value obtained for the Ca-PiPhtA-I sample after thermal activation is of the same magnitude as for other functionalized metal phosphonates (from $1.6 \times 10^{-3}$ to $8 \times 10^{-3}$ $\left.\mathrm{S} \cdot \mathrm{cm}^{-1}\right)^{18,19}$ and other MOF materials, some of them reaching $10^{-2} \mathrm{~S} \cdot \mathrm{cm}^{-1} \cdot{ }^{15 \mathrm{~g}, \mathrm{f}}$ However, the proton conductivity of Ca-PiPhtA

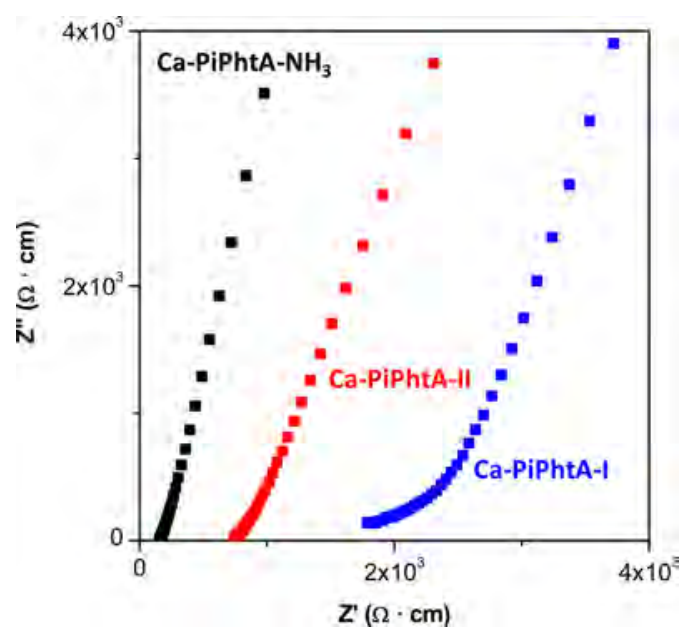

Figure 10. Plot of the complex impedance plane for Ca-PiPhtA compounds at $24^{\circ} \mathrm{C}$ and $98 \% \mathrm{RH}$.

materials is higher than those reported for other Ca-based MOFs, the latter exhibiting values in the range from $10^{-5}$ to $4 \times 10^{-4} \mathrm{~S} \cdot \mathrm{cm}^{-1}$ under similar experimental conditions. ${ }^{34,35}$

As observed in Figure 11, the proton conductivity of Ca-PiPhtA-III remains practically constant up to $\sim 40{ }^{\circ} \mathrm{C}$,

Temperature $\left({ }^{\circ} \mathrm{C}\right)$

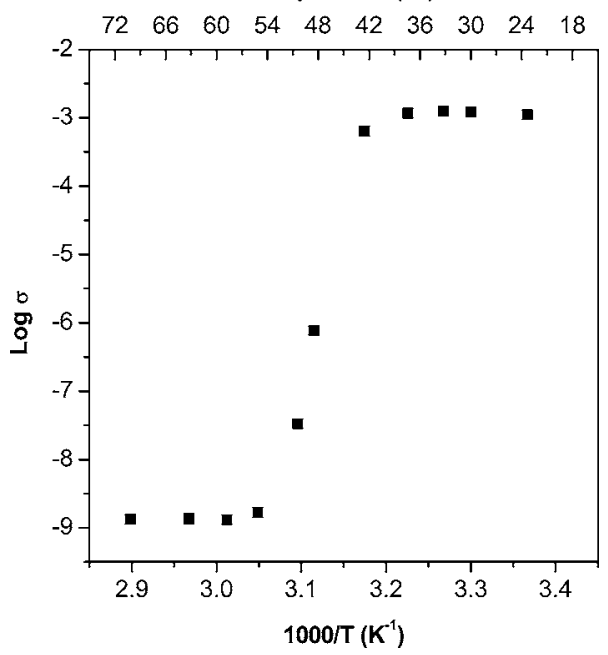

Figure 11. Plot of $\log \sigma$ vs $1000 / T$ for Ca-PiPhtA-III from 24 to $75^{\circ} \mathrm{C}$.

notwithstanding the relative humidity is progressively decreasing. Higher temperatures cause a profound drop in conductivity, most likely due to dehydration, according to the TG curve. This behavior is characteristic of water-mediated proton conductors when a drastic reduction in proton carrier number occurs. ${ }^{15 \mathrm{~d}}$

As the nature and size of the internal cavities may strongly influence the proton conductivity behavior, it was decided to measure the conductivity of the $\mathrm{NH}_{3}$ derivative, which can host a considerably high number of proton carriers and thus possesses impressive swelling properties. As shown in Figure 10, CaPiPhtA- $\mathrm{NH}_{3}$ exhibits the highest proton conductivity in the selected temperature range. The maximum conductivity value measured at $98 \% \mathrm{RH}$ and $\mathrm{T}=24^{\circ} \mathrm{C}$ was $6.6 \times 10^{-3} \mathrm{~S} \cdot \mathrm{cm}^{-1}$. These results underline the importance of internal H-bonding networks that, in turn, determine conductivity properties of hybrid materials. Additionally, post-synthetic cavity "derivatization" 
with selected guest molecules may enhance these properties by creating new proton transfer pathways.

The activation energies $\left(E_{\mathrm{a}}\right)$ for the proton transfer in Ca-PiPhtA-I, Ca-PiPhtA-III, and Ca-PiPhtA-NH $\mathrm{NH}_{3}$ range between 0.23 and $0.4 \mathrm{eV}$ (Figure 12). Preheating the sample at

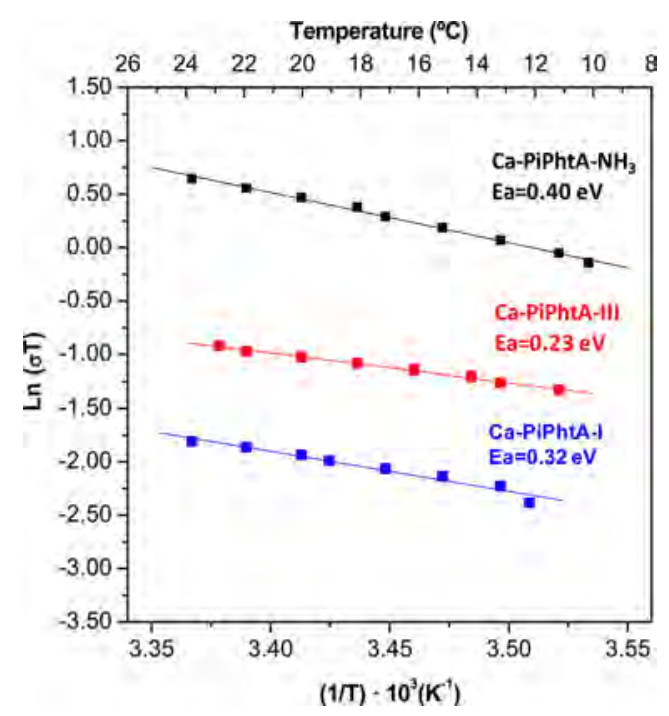

Figure 12. Arrhenius plots vs $T^{-1}$ from 10 to $24{ }^{\circ} \mathrm{C}$.

$40{ }^{\circ} \mathrm{C}$ seems to induce small structural distortions favorable for proton transfer through a pathway of sites separated by a smaller energy barrier. ${ }^{15 f, 16}$ The activation energy of Ca-PiPhtA- $\mathbf{N H}_{3}$ although increased with respect to the two other Ca-PiPhtA compounds is still within the range of values consistent with the Grotthuss $\mathrm{H}^{+}$transfer mechanism. ${ }^{36}$

\section{CONCLUSION}

We reported the synthesis, structural characterization, and some important properties (framework interconversions and proton conductivity) of an open-framework hybrid material containing $1 \mathrm{D}$ channels filled with hydrogen-bonded water molecules, namely, $\mathrm{Ca}_{2}\left[\left(\mathrm{HO}_{3} \mathrm{PC}_{6} \mathrm{H}_{3} \mathrm{COOH}\right)_{2}\right]_{2}\left[\left(\mathrm{HO}_{3} \mathrm{PC}_{6} \mathrm{H}_{3}(\mathrm{COO})_{2} \mathrm{H}\right)\right.$ $\left.\left(\mathrm{H}_{2} \mathrm{O}\right)_{2}\right] \cdot 5 \mathrm{H}_{2} \mathrm{O}$ (Ca-PiPhtA-I). Its partial dehydration at $75{ }^{\circ} \mathrm{C}$ produces Ca-PiPhtA-II, which exhibits lower water content but otherwise retains the framework structural features of its parent Ca-PiPhtA-I. Structure solution using synchrotron powder X-ray diffraction data revealed its molecular formula $\mathrm{Ca}_{2}\left[\left(\mathrm{HO}_{3} \mathrm{PC}_{6} \mathrm{H}_{3} \mathrm{COOH}\right)_{2}\right]_{2}\left[\left(\mathrm{HO}_{3} \mathrm{PC}_{6} \mathrm{H}_{3}(\mathrm{COO})_{2} \mathrm{H}\right)\left(\mathrm{H}_{2} \mathrm{O}\right)_{2}\right]$. Upon Ca-PiPhtA-I exposure to ammonia vapors (28\% aqueous $\mathrm{NH}_{3}$ ) a new derivative is obtained (Ca-PiPhtA- $\mathbf{N H}_{3}$ ) containing $7 \mathrm{NH}_{3}$ and $16 \mathrm{H}_{2} \mathrm{O}$ molecules. The above-mentioned materials were studied for proton conductivity. At $98 \% \mathrm{RH}$ and $\mathrm{T}=24^{\circ} \mathrm{C}$, proton conductivity for Ca-PiPhtA-I is $5.7 \times 10^{-4} \mathrm{~S} \cdot \mathrm{cm}^{-1}$. The proton conductivity properties of this phase can be enhanced up to $1.3 \times 10^{-3} \mathrm{~S} \cdot \mathrm{cm}^{-1}$ by activation upon preheating the sample at $40{ }^{\circ} \mathrm{C}$ for $2 \mathrm{~h}$ followed by water equilibration. Ca-PiPhtA- $\mathbf{N H}_{3}$ exhibits the highest proton conductivity, $6.6 \times 10^{-3} \mathrm{~S} \cdot \mathrm{cm}^{-1}$, measured at $98 \% \mathrm{RH}$ and $\mathrm{T}=24^{\circ} \mathrm{C}$. Activation energies $\left(E_{\mathrm{a}}\right)$ for proton transfer in the above-mentioned frameworks range between 0.23 and $0.4 \mathrm{eV}$, typical of a Grothuss mechanism of proton conduction. These results emphasize the significance of internal $\mathrm{H}$-bonding networks and their profound effect on conductivity properties, at least in the case of Ca-PiPhtA-I. Finally, cavity "derivatization" with selected guest molecules may be an important mechanism to create new proton transfer pathways that improve the proton conductivity.

\section{ASSOCIATED CONTENT}

\section{Supporting Information}

ATR-IR spectra for Ca-PiPhtA-I and Ca-PiPhtA-NH ${ }_{3}$; Rietveld refinement powder XRD profile of Ca-PiPhtA-II; powder X-ray diffraction patterns for (a) Ca-PiPhtA-I and (b) Ca-PiPhtA$\mathbf{N H}_{3}$; plot of $\log \sigma$ vs time for Ca-PiPhtA-I and Ca-PiPhtA-III for two cycles; table of bond lengths and $\mathrm{H}$-bond distances for Ca-PiPhtA-I; CIF files for Ca-PiPhtA-I and Ca-PiPhtA-II. This material is available free of charge via the Internet at http://pubs. acs.org.

\section{AUTHOR INFORMATION}

\section{Corresponding Authors}

demadis@chemistry.uoc.gr. (K.D.D.)

aurelio@uma.es (A.C.)

\section{Author Contributions}

The manuscript was written through contributions of all authors. All authors have given approval to the final version of the manuscript.

Notes

The authors declare no competing financial interest.

\section{ACKNOWLEDGMENTS}

ALBA synchrotron is thanked for providing synchrotron beamtime at BL04-MSPD beamline. The project "Factoria de Cristalización, CONSOLIDER INGENIO-2010” provided Xray diffraction facilities for this work. The work at UMA was funded by a MAT2010-15175 research grant (Spain) which is cofunded by FEDER. The work at the UoC was supported by grants from the Research Committee of the University of Crete, ELKE (KA 3517 and KA 3806). The work at Wrocław University of Technology was founded by The Faculty of Chemistry and the Faculty of Mechanical and Power Engineering.

\section{REFERENCES}

(1) (a) Special thematic issue on Metal Organic Frameworks. Chem. Rev. 2012, 112 (2), 673-702. (b) Special thematic issue on Hybrid Materials. Chem. Soc. Rev. 2011, 40 (2), 453-1152. (c) Themed issue on Metal-Organic Frameworks. Chem. Soc. Rev. 2009, 38, 1201-1508. (d) Wang, Z. Q.; Cohen, S. M. Chem. Soc. Rev. 2009, 38, 1315-1329.

(2) (a) Jiang, H.-L.; Xu, Q. Chem. Commun. 2011, 47, 3351-3370. (b) Suh, M. P.; Park, H. J.; Prasad, T. K.; Lim, D.-W. Chem. Rev. 2012, 112, 782-835. (c) Functional Metal-Organic Frameworks: Gas Storage, Separation and Catalysis. In Topics in Current Chemistry; Schröder, M., Ed.; Springer: New York, 2010; Vol. 293.

(3) (a) Mondal, S. S.; Bhunia, A.; Demeshko, S.; Kelling, A.; Schilde, U.; Janiakb, C.; Holdt, H.-J. CrystEngComm. 2014, 16, 39-42. (b) Lago, A. B.; Carballo, R.; Fabelo, O.; Fernández-Hermida, N.; Lloretd, F.; Vázquez-López, E. M. CrystEngComm. 2013, 15, 10550-10562.

(4) (a) Yoon, M.; Srirambalaji, R.; Kim, K. Chem. Rev. 2012, 112, 1196-1231. (b) Gu, X.; Su, H. Mater. Focus 2012, 1, 97-111. (c) Gu, Z.Y.; Park, J.; Raiff, A.; Wei, Z.; Zhou, H.-C. ChemCatChem. 2013, DOI: $10.1002 /$ cctc.201300493.

(5) (a) Liu, D.; Lu, K.; Poon, C.; Lin, W. Inorg. Chem. 2014, 53, 19161924. (b) Kreno, L. E.; Leong, K.; Farha, O. K.; Allendorf, M.; Van Duyne, R. P.; Hupp, J. T. Chem. Rev. 2012, 112, 1105-1125. (c) Manos, M. J.; Moushi, E. E.; Papaefstathiou, G. S.; Tasiopoulos, A. J. Cryst. Growth Des. 2012, 12, 5471-5480.

(6) (a) Devic, T.; Serre, C. In Ordered Porous Solids, Recent Advances and Propects; Valtchev, V., Mintova, S., Tsapatsis, M., Eds.; Elsevier B.V.: New York, 2009; Chapter 4, pp 77-99. (b) Su, C.-Y.; Qin, C.; Wang, X.-L.; 
Su, Z.-M. Expert Opin. Drug Delivery 2013, 10, 89-101. (c) Demadis, K. D.; Theodorou, I.; Paspalaki, M. Ind. Eng. Chem. Res. 2011, 50, 58735876. (d) Horcajada, P.; Serre, C.; Maurin, G.; Ramsahye, N. A.; Balas, F.; Vallet-Regí, M.; Sebban, M.; Taulelle, F.; Férey, G. J. Am. Chem. Soc. 2008, 130, 6774-6780.

(7) (a) Nickerl, G.; Henschel, A.; Grünker, R.; Gedrich, K.; Kaskel, S. Chem. Ing. Tech. 2011, 83, 90-103. (b) Jiang, H.-L.; Xu, Q. Chem. Commun. 2011, 47, 3351-3370. (c) Dong, D.-P.; Li, J.; Sun, Z.; Zheng, X.; Chen, H.; Meng, L.; Zhu, Y.; Zhao, Y.; Zhang, J. Inorg. Chem. Commun. 2007, 10, 1109-1112.

(8) Kim, M.; Cahill, J. F.; Fei, H.; Prather, K. A.; Cohen, S. M. J. Am. Chem. Soc. 2012, 134, 18082-18088.

(9) (a) Prasad, T. K.; Hong, D. H.; Suh, M. P. Chem.-Eur. J. 2010, 16, 14043-14050. (b) Xue, D.-X.; Cairns, A. J.; Belmabkhout, Y.; Wojtas, L.; Liu, Y.; Alkordi, M. H.; Eddaoudi, M. J. Am. Chem. Soc. 2013, 135, 7660-7667. (c) Eubank, J. F.; Mouttaki, H.; Cairns, A. J.; Belmabkhout, Y.; Wojtas, L.; Luebke, R.; Alkordi, M. H.; Eddaoudi, M. J. Am. Chem. Soc. 2011, 133, 14204-14207. (d) Eubank, J. F.; Wojtas, L.; Hight, M. R.; Bousquet, T.; Kravtsov, V. C.; Eddaoudi, M. J. Am. Chem. Soc. 2011, 133, 17532-17535.

(10) (a) Zhun, H.; Huang, J.; Bao, S.-S.; Ren, M.; Zheng, L.-M. CrystEngComm 2013, 15, 10316-10322. (b) He, G.; Li, Y.; Li, Z.; Nie, L.; Wu, H.; Yang, X.; Zhao, Y.; Jiang, Z. J. Power Sources 2014, 248, 951961. (c) Białek, M. J.; Janczak, J.; Zoń, J. CrystEngComm 2013, 15, 390399.

(11) (a) Deng, M.; Liu, X.; Zheng, Q.; Chen, Z.; Fang, C.; Yue, B.; He, H. CrystEngComm. 2013, 15, 7056-7061. (b) Schilling, L.-H.; Stock, N. Dalton Trans. 2014, 43, 414-422. (c) In Metal phosphonate chemistry: From synthesis to applications; Clearfield, A.;, Demadis, K. D., Eds.; The Royal Society of Chemistry: London, 2012; Chapter 4, pp 107-132.

(12) (a) Zima, V.; Svoboda, J.; Melanova, K.; Benes, L.; Casciola, M.; Sganappa, M.; Brus, J.; Trchova, M. Solid State Ionics 2010, 181, 705713. (b) Aberti, G.; Casciola, M.; Palombari, R.; Peraio, A. Solid State Ionics 1992, 58, 339-344. (c) Jang, M. Y.; Park, Y. S.; Yamazaki, Y. Electrochemistry 2003, 71, 691-694.

(13) (a) Jiménez-García, L.; Kaltbeitzel, A.; Enkelmann, V.; Gutmann, J. S.; Klapper, M.; Müllen, K. Adv. Funct. Mater. 2011, 21, 2216-2224. (b) Yoon, M.; Suh, K.; Kim, H.; Kim, Y.; Selvapalam, N.; Kim, K. Angew. Chem. Int. Ed. 2011, 50, 7870-7873. (c) Jiménez-García, L.; Kaltbeitzel, A.; Pisula, W.; Gutmann, J. S.; Klapper, M.; Müllen, K. Angew. Chem. Int. Ed. 2009, 48, 9951-9953.

(14) (a) Malavasi, L.; Fisher, C. A. J.; Islam, M. S. Chem. Soc. Rev. 2010, 39, 4370-4387. (b) Zayas-Rey, M. J.; Santos-Gomez, L. D.; Marrero, D.; Leon-Reina, L.; Canales-Vazquez, J.; Aranda, M. A. G.; Losilla, E. R. Chem. Mater. 2013, 25, 448-456. (c) Dos Santos-Gómez, L.; LeónReina, L.; Porras-Vázquez, J. M.; Losilla, E. R.; Marrero-López, D. Solid State Ionics 2013, 239, 1-7.

(15) (a) Horike, S.; Umeyama, D.; Kitagawa, S. Acc. Chem. Res. 2013, 46, 2376-2384. (b) Thanganathan, U.; Nogami, M. J. Solid State Electrochem. 2014, 18, 97-104. (c) Colodrero, R. M. P.; Papathanasiou, K. E.; Stavgianoudaki, N.; Olivera-Pastor, P.; Losilla, E. R.; Aranda, M. A. G.; León-Reina, L.; Sanz, J.; Sobrados, I.; Choquesillo-Lazarte, D.; García-Ruiz, J. M.; Atienzar, P.; Rey, F.; Demadis, K. D.; Cabeza, A. Chem. Mater. 2012, 24, 3780-3792. (d) Yoon, M.; Suh, K.; Natarajan, S.; Kim, K. Angew. Chem., Int. Ed. 2013, 52, 2688-2700. (e) Sadakiyo, M.; Yamada, T.; Kitagawa, H. J. Am. Chem. Soc. 2009, 131, 9906-9907. (f) Kim, S.; Dawson, K. W.; Gelfand, B. S.; Taylor, J. M.; Shimizu, G. K. H. J. Am. Chem. Soc. 2013, 135, 963-966. (g) Ponomareva, V. G.; Kovalenko, K. A.; Chupakhin, A. P.; Dybtsev, D. N.; Shutova, E. S.; Fedin, V. P. J. Am. Chem. Soc. 2012, 134, 15640-15643.

(16) (a) Shimizu, G. K. H.; Taylor, J. M.; Kim, S. Science 2013, 341, 354-355. (b) Taylor, J. M.; Dawson, K. W.; Shimizu, G. K. H. J. Am. Chem. Soc. 2013, 135, 1193-1196. (c) Aubrey, M. L.; Ameloot, R.; Wiers, B. M.; Long, J. R. Energy Environ. Sci. 2014, 7, 667-671.

(17) Costantino, F.; Donnadio, A.; Casciola, M. Inorg. Chem. 2012, 51, 6992-7000.

(18) Colodrero, R. M.P.; Olivera-Pastor, P.; Losilla, E. R.; HernándezAlonso, D.; Aranda, M. A. G.; Leon-Reina, L.; Rius, J.; Demadis, K. D.;
Moreau, B.; Villemin, D.; Palomino, M.; Rey, F.; Cabeza, A. Inorg. Chem. 2012, 51, 7689-7698.

(19) Colodrero, R. M. P.; Olivera-Pastor, P.; Losilla, E. R.; Aranda, M. A. G.; Leon-Reina, L.; Papadaki, M.; McKinlay, A. C.; Morris, R. E.; Demadis, K. D.; Cabeza, A. Dalton Trans. 2012, 41, 4045-4051.

(20) Grahl, A. J. Chem. Abstr. 1895, 28, 84-90.

(21) Boomgaarden, W.; Voegtle, F.; Nieger, M.; Hupfer, H. Chem.Eur. J. 1999, 5, 345-355.

(22) Bruker, APEX2 Software, V2012.2; Bruker AXS Inc.: Madison, WI, 2012.

(23) Sheldrick, G. M. SADABS, Program for Empirical Absorption Correction of Area Detector Data; University of Göttingen: Göttingen, Germany, 2012.

(24) Sheldrick, G. M. Acta Crystallogr. 2008, A64, 112-122.

(25) Knapp, M.; Peral, I.; Nikitina, L.; Quispe, M.; Ferrer, S. Z. Kristallogr. Proc. 2011, 1, 137-142.

(26) Boultif, A.; Louër, D. J. Appl. Crystallogr. 2004, 37, 724-731.

(27) Rietveld, H. M. J. Appl. Crystallogr. 1969, 2, 65-71.

(28) (a) Toby, B. H. J. Appl. Crystallogr. 2001, 34, 210-213. (b) Larson, A. C.; von Dreele, R. B. General Structure Analysis System (GSAS), Los Alamos National Laboratory Report LAUR 86-748, Los Alamos, NM, USA; 2004.

(29) winDETA; Novocontrol GmbH: Hundsangen, Germany, 1995.

(30) Bauer, S.; Stock, N. J. Solid State Chem. 2007, 180, 3111-3120.

(31) (a) Danilich, M. J.; Burton, D. J.; Marchant, R. E. Vibr. Spectrosc. 1995, 9, 229-234. (b) Chaplais, G.; Le Bideau, J.; Leclercq, D.; Vioux, A. Chem. Mater. 2003, 15, 1950-1956. (c) Demadis, K. D.; Katarachia, S. D. Phosphorus Sulfur Silicon 2004, 179, 627-640. (d) Kim, C. S.; Lad, R. J.; Tripp, C. P. Sens. Actuators B: Chem. 2001, 76, 442-448.

(32) (a) Gómez-Alcántara, M. M.; Aranda, M. A. G.; Olivera-Pastor, P.; Beran, P.; García-Muñoz, J. L.; Cabeza, A. Dalton Trans. 2006, 577-585. (b) Gómez-Alcántara, M. M.; Cabeza, A.; Aranda, M. A. G.; Guagliardi, A.; Mao, J. G.; Clearfield, A. Solid State Sci. 2004, 6, 479-487.

(33) Zenobi, M. C; Luengo, C. V.; Avena, M. J.; Rueda, E. H. Spectrochim. Acta A 2008, 70, 270-276.

(34) Liang, X.; Zhang, F.; Feng, W.; Zou, Z.; Zhao, C.; Na, H.; Liu, C.; Suna, F.; Zhu, G. Chem. Sci. 2013, 4, 983-992.

(35) Kundu, T.; Sahoo, C.; Banerjee, R. Chem. Commun. 2012, 48, 4998-5000.

(36) Colomban, P. Proton Conductors: Solids, Membranes and Gels Materials and Devices. Chemistry of Solid State Materials; Cambridge University Press: Cambridge, U.K., 1992; Vol. 2. 